\title{
The Role of the Public Power District
}

\section{E. Kendell Davis*}

Even though we in the United States are amply endowed with fundamental natural resources, we are becoming increasingly aware of our limitations. Recent years of drought, population increases, population movement, and expanded agricultural production have made us cognizant that widespread water conservation programs are essential to meet future demands. Water problems in our country have been and remain most acute in the semi-arid western areas, including, of course, the State of California. This was recognized in the passage of the Reclamation Act of $1902,{ }^{1}$ which introduced the federal government into the water business in the seventeen western states. Although in very recent years the mid-western and eastern sections of the country have shown real concern for water conservation, previously their interests were confined to flood control and navigation.

One interesting aspect of water development in the West is that during the early days it was largely in the hands of local orgamizations, both public and private, while later there came a pronounced swing toward reliance on the federal government. This movement reached its zenith during the presidency of Franklin D. Roosevelt. Recently, particularly during the Eisenhower administration, there has been renewed emphasis on state and local responsibility. ${ }^{2}$

California has long been conscious of water, and in recent years that consciousness has become acute. Evidence of this exists in the great interest in and activity on water problems in the 1957 session of the state legislature ${ }^{3}$ in the creation of the Department of Water Resources in 1956 to consolidate and expand conservation functions, ${ }^{4}$ in the formulation of The California Water Plan, ${ }^{5}$ and in the commencement of the immense Feather River Project. ${ }^{6}$ This increased emphasis on water problems can be traced

* General Counsel, Sacramento Municipal Utility District.

132 StaT. 388 (1902) (codified in scattered sections of 43 U.S.C. from $\$ \$ 372$ through 498 ).

2 The most recent example of this new trend and the one closest to home is the proposal to dispose of the "falling water" from the Trinity River Project to the Pacific Gas and Electric Company. The project, including the power features, now is authorized to the Bureau of Recla mation. 69 STAT. 719 (1955). The Secretary of the Interior has recommended acceptance of the P.G.\&E. offer and a bill was introduced in Congress to authorize it. H.R. 6997, 85th Cong., 1st Sess. (1957). This bill was never reported out by the House Committee on Interior and Insular Affairs.

${ }^{3}$ Some 700 proposals relating to water conservation were introduced in the 1957 session of the state legislature.

${ }^{4}$ Cad. Water Code $\$ \$ 150-59$.

5 Caltfornia Departament of Water Resources, Butyetin No. 3, The Catifornta Water PLAN (1957).

${ }^{6}$ Cat. Water Code $\S 11260$. 
to the continuous growth of population that began during World War II and to the increased demands for California agricultural produce brought about by the general increase in population throughout the county. With this expanded water demand has come the need for more electrical power to satisfy demands created by new homes and new industry, to pump irrigation water, and to earn revenue for the financing of costly projects.

\section{POWER PROBLEMS-CALIFORNIA'S EXPERIENCE}

Except for some inconclusive provisions in the Central Valley Project Act enacted by the legislature in $1933,{ }^{7}$ California has established no policy with reference to the production and disposition of power. In connection with the Central Valley Project, sections 11205 and 11225 of the California Water Code authorized construction of a power plant at Shasta Dam, a transmission lime to Antioch, and a plant at Friant Dam. Section 11260 authorized the Feather River Project in accordance with certain state reports, which contemplated generators but not transmission lines at the Oroville Dam. Section 11295 authorized steam-firming plants and transmission lines as necessary in the opinion of the Water Project Authority, to make a "reasonable, proper, and advantageous sale, use, and distribution" of hydro power generated. The all-important policy decision as to whether these features were needed was left in the hands of the Authority. Section 11626 accords a so-called preference to public agencies in the purchase of power and water but only "in case of equal or equivalent offers." In case of contracts awarded to public agencies, section 11650 would require the Authority to provide necessary transmission facilities. Of course, in light of section 11626, this latter section would not be utilized if a non-preference entity should make the highest bid. Section 11670 calls for a five-year cancellation provision in all contracts with private agencies.

From the standpoint of the activities of public power districts, these provisions were steps in the right direction, but they have never been applied because the main features of the Central Valley Project have been built by the federal governnent and the state's Feather River Project is just now under way. Thus, their effect is uncertain. If the Department of Water Resources, the successor to the Water Project Authority, ${ }^{8}$ decides under its broad administrative discretion to sell the power for the highest possible price, there will be no real protection for public power agencies. This course apparently will be followed on the Feather River Project, where

7 CAL. WATER CODE $\$ \S 11100-855$.

8 Under CAI. WATER CODE $\S 153$, added in 1956, authority under these statutes is now vested in the Department of Water Resources. 
plans suggest installation of the power plants by the state and sale of the power at the bus bar to the highest bidder. ${ }^{\circ}$ The cost of the project is such as to require sale of power for the highest possible price in order to bring the cost of water within reasonable limits. Thus, while there has been some indication of policy in specific areas, as yet the state has made no over-all basic policy decisions on power.

THE CALIFORNIA WATER PLAN AND SOME BASIC QUESTIONS FOR THE FUTURE

This year, the State Department of Water Resources proposed The California Water Plan ${ }^{10}$ for the future development of the state's water resources. The role of the local public power agencies will in large part be determined by their relationships to this plan. In this regard, basic questions which must be resolved can best be considered by setting up a hypothetical example: Assume that a large multiple-purpose project is built by the state. The total cost is $\$ 100$ million and a fair allocation of costs is: power, $\$ 25$ million; non-reimbursable items, such as flood control, navigation, and recreation, $\$ 25$ million; consumptive water-domestic, industrial, and irrigation- $\$ 50$ million.

The first question to be resolved is: at what price shall the power be sold? If it should be disposed of at full market price, the water users would get water essentially free, or at least for paynent of operation and maintenance expenses. The consumptive user would be fully subsidized. The power consumer would get none of the benefits of the public development. At the other extreme, the power could be sold for an amount sufficient only to repay the $\$ 25$ million power allocation, plus operating costs. Full benefits would then flow to the power consumer but the project would be financially infeasible and would not be built unless there were a direct state subsidy. A middle course, and one historically followed by the federal government, would be to establish power rates sufficient to repay the $\$ 25$ million plus 40 per cent of the water allocation-a total of $\$ 45$ million-and water rates sufficient to realize $\$ 30$ million. Here consumptive water would be heavily subsidized by the power consumers but this group would also get some of the benefits from the public project.

If the state answers this first question by deciding to sell all the power potential at the highest price possible, probably very little of it will go to public agencies. Private compamies have done and will continue to do every-

\footnotetext{
- Californita Departmatet of Public Works, Divisyon of Water Resources, Programs for Fivancing and Constructing the Frather Rtver Project 3-4, 50-51 (1955).

10 Calffornia Department of Water Resources, Bull. No. 3, The Cairfornta Water PLAN (1957).
} 
thing possible to prevent expansion of public power development. One simple and effective way to help accomplish this is to purchase any power that a public agency might otherwise purchase and distribute it at low cost. Furthermore, hydroelectric power is often more valuable for peaking purposes in large and diversified power systems, thus giving the private companies an advantage in bidding. If the power is to be sold at the bus bar or as falling water-and likely this would be the way to realize the greatest returns-another decided advantage would accrue to the private companies, in that only such large organizations can afford the high cost of transmission. ${ }^{11}$

A second question is: Should the state build the power plants? If it does, it will have increased greatly the opportunity for participation by public power agencies. Few public agencies have the capital to construct large hydroelectric developments even if the price for falling water were reasonably low.

Third: Should the state build transmission limes? If it does, it will substantially imcrease the opportunity for local participation. Except for projects built in close proximity to the area served by local public power agencies, few public districts could finance the necessary transmission hines.

Fourth: Should the state, either through construction of its own steam plants or by contracts with agencies having steam plants, firm up its hydroelectric production? The hydroelectric power produced from California streams is most valuable when combined with fuel plants; this is particularly true with respect to power available from projects operated primarily to serve other purposes. The water release patterns are sucli that only relatively small loads can be accommodated from the hydroelectric plant when it is operated alone. Another consequence is that much energy is wasted. But, with the addition of fuel plants, the total output of firm power increases enonnously. However, few local power agencies are in a position financially to firm up hydroelectric generation.

Fifth: Should public agencies, including agencies of the state itself, be accorded preference in the purchase of power? Such a preference in the purchase of power would be most valuable where a fixed price has been estabhished. As has already been indicated, a preference tied to competitive bidding is advantageous to the private compamies. There are numerous federal preference laws giving public agencies of all kinds first opportunity to obtain power privileges from resource developments built with taxpay-

11 The recent experience on the Trinity River Project is a good example. Although invitations to bid were distrihuted widely by the federal government, only the Pacific Gas and Electric Company made an offer. H.R. Doc. No. 94, 85th Cong., 1st Sess. 5 (1957). No other agency, pubkic or private, could afford the expenditures necessary to transport the power from its point of production to its point of use. 
ers' dollars. ${ }^{12}$ The basis of these laws seems clear; if public funds are used to construct the project, then public agencies should have first preference to buy the low-cost power and pass the savings on to the power-consuming public. Unquestionably, adoption by California of a preference law similar to the federal law, in combination with a pricing policy that would pass on to the power users some of the benefits of public development, would assure widespread participation in The California Water Plan by local power districts.

\section{III}

\section{THE INDEPENDENT ROLE OF THE LOCAL AGENCY-SONE EXPERIENCES} OF THE SACRAMENTO MUNICIPAL UTILITY DISTRICT

Will local agencies be able to develop water and power resources without outside assistance? If the proposed California Water $\mathrm{Plan}^{13}$ is adopted by the legislature, presumptively it will be sufficiently flexible to permit local participation by actual construction and operation of given segments of the plan. Powerwise, the Plan indicates a potential of seven million kilowatts and thirty-two billion kilowatt-hours, nearly as much as the total power consumption in California today. Full development will require the coordination of all levels of government and private capital as well.

In keeping with this basic requirement of coordination, how can local power districts themselves develop portions of the state's water resources? The Sacramento Municipal Utility District is now in the midst of undertaking a local project of considerable proportion-an $\$ 85$ mlilion development on the upper Annerican River. A brief presentation of the legal and policy problems facing the District will demonstrate the manner in which a municipal utility district in the power business can participate in a coordinated plan for water resource development.

1234 STaT. 117 (1906), as amended, 43 U.S.C. $\$ 522$ (1952); Raker Act of Dec. 19, 1913, c. 4, § 6, 38 Stat. 245; Federal Power Act § 7, 41 Stat. 1067 (1920), as amended, 16 U.S.C. $\$ 800$ (a) (1952); 42 Star. 847 (1922), 43 U.S.C. $\$ 598$ (1952) (Salt River Project); Boulder Canyon Project Act § 5, 45 Star. 1060 (1928), 43 U.S.C. \$ 617d (1952); Tennessee Valley Authority Act of $1933 \S 10,48$ STAT. 64, as amended, 16 U.S.C. $\$ 8311$ (1952); Rural Electrification Act of $1936 \$ 4,49$ STar. 1365, as amended, 7 U.S.C. $\$ 904$ (Supp. IV, 1957); Bonneville Project Act $\$ 4,50$ STat. 733 (1937), as amended, 16 U.S.C. \& 832c (1952); 52 StaT. 405 (1938), 16 U.S.C. \& 833c (1952); Reclamation Project Act of 1939 \$ 9(c), 53 Stat. 1194, 43 U.S.C. \$ 485h (1952); Water Conservation and Utilization Act $\$ 9$, 54 STaT. 1124 (1940), 16 U.S.C. $\S 590 z-7$ (1952) ; 58 Star. 890 (1944), 16 U.S.C. $\$ 825$ s (1952), River and Harbor Act of 1945, c. 19, §2, 59 StaT. 22; Act of July 31, 1950, c. 510, § 2, 64 StaT. 382 (Eklutna Project); Act of June 18, 1954, c. 310, § 1, 68 Stat. 255 (Falcon Dam); Atomic Energy Act of $1954 \$ \S 44,182 c$, 68 Stat. 929, 954, 42 U.S.C. $\$ \S 2064,2232$ (c) (Supp. IV, 1957) ; Trinity River Division Act of Aug. 12, 1955, c. 872, § 4, 69 STat. 720; Small Reclamation Projects Act of 1956 \$(f), 70 StaT. 1046, as amended, 43 U.S.C. $\$ 422$ e (Supp. IV, 1957). See also Niagara River Hydroelectric Power Project Act, Pub. L. No. 85-159, 85th Cong., 1st Sess. §1(b) (1) (Aug. 21, 1957).

13 Cautfornis Departament of Water Resources, Bult. No. 3, The Cartfornia Water PlaN (1957). 
For many years a water and power project in the upper portion of the American River watershed had been contemplated, alternately by the City of Sacramento and by the Sacramento Municipal Utility District. In 1948, the Utility District filed applications for state water rights, ${ }^{14}$ and in 1952 it filed applications for the necessary license and permit from the Federal Power Commission. ${ }^{15}$ Aside from raising the necessary capital for such a venture, obtaining of these permits and licenses is one of the most timeconsuming, costly, and often discouraging problem facing a local power agency, whether public or private. Let us first consider the matter of state water rights permits. The situation on the American River is lighly involved and competitive. In hearings before the State Water Rights Board, which commenced in November 1956, there were twenty-two applicants for permits and seventy-three protestants. The Sacramento Municipal Utility District filed for water not only for power purposes but for consumptive uses as well, with an understanding with the City of Sacramento that, if possible, arrangements would be made to turn over to the City consumptive-use applications or permits. However, both the City and the County of Sacramento made their own applications for water from the river.

In 1955 and 1956, when the Utility District actively began to pursue its applications, the California Water Plan was in active fornulation. Prior to creation of the Department of Water Resources in April 1956, ${ }^{16}$ water permits were under the jurisdiction of the State Engineer, who also was a member of the State Water Resources Board. California law requires that appropriations be made under terms which will "best develop, conserve, and utilize in the public interest the water sought to be appropriated."17 In other words, the proposed use slould fit an over-all plan and slould make adequate and comprehensive use of the water.

The planning function was under the State Water Resources Board, served by the staff of the then Division of Water Resources, which in turn was under the State Engineer who decided whether to issue permits; it was evident that a first necessary step was to convince the Board that the District's plan would result in reasonably adequate development of the water resources of the area. Accordingly, hearings were souglit. In the meantime, prelimimary drafts of a comprehensive plan for the American River watershed were published by the state, ${ }^{18}$ indicating features at variance with those proposed by the Utility District. It is a rare situation where all parties

14 Applications Nos. 12323, 12624, and 14963 led to Permits Nos. 10703, 10704, and 10705, issued in May, $195 \%$.

15 Federal Power Commission Projects Nos. 2101 and 2155.

10 CaI. Water Code $\$ \S 150-59$.

17 Cas. Water Code $\$ 1253$.

18 California Water Resources Board, BuLI. No. 21, Amertcan River Basta Investigation, Report on Deveiopaient Proposed for The Catifornia Water Plan (1955). 
involved agree on one plan which, exclusive of all others, is the best. In order to demonstrate that the District's suggested hydroelectric development would fit into an over-all plan resulting in full development of the entire basin, extensive studies were made by a board of distinguished consulting engineers. They developed modifications showing how, with certain variations in the state proposal, the District's plan could be fully accommodated. After a hearing and much discussion, state interests agreed with the District's approach, provided a third alternative scheme for a portion of the basin were examined. As a result, the State Water Resources Board on June 1,1956, adopted a resolution requiring the District to investigate this possibility and to report to the Director of Water Resources whether such an alternative was more feasible. ${ }^{10}$

At about the same time, the state administrative set-up for handling water underwent a thorough overhauling. ${ }^{20}$ The State Water Resources Board was abolished and replaced by an advisory State Water Board. Except for issuance of water permits, essentially all state water problems were turned over to a new Department of Water Resources. The State Water Rights Board was created to handle water rights, although jurisdiction of all state filings formerly made by the Director of Finance was placed under the Department. ${ }^{21}$ Although the State Water Rights Board would issue the permits, with control of state filings in the hands of the Department and with responsiblity for resource planning there also, it seemed unlikely that the Board would issue a permit if there were serious opposition from the Department.

On November 2, 1956, the Sacramento Municipal Utility District filed its report on the alternative proposed by the state, finding it to be less feasible than the District's original plan. ${ }^{22}$ On November 27 , the State Water Rights Board began its American River hearings. The procedure followed in these hearings was somewhat novel and may be of interest. Because there were twenty-two applicants and seventy-three protestants, it was evident that the hearings would extend over a long period of time. The Sacraniento Municipal Utility District had held an election and had secured overwhelming approval for a bond issue to finance the project, and it was urgent that construction start at the earliest possible date in order to meet its load growth. Accordingly, the Utility District suggested various alternatives in order to speed up a decision on its request for power permits. One alternative was to stage the hearings, limiting the first stage to non-consumptive uses; another was to limit the first stage geographically to the upper por-

\footnotetext{
${ }^{19}$ Catifornia Water Resources Board, Res. No. 285, June 1, 1956.

20 Cal. Stat. 1956, c. 52.

21 See Car. Water Code $\S 10500$.

22 Sacramento Muntcipat Utitity District, Report on Substitute Pian, Amerricat RTVER BASIN (1956).
} 
tion of the watershed. The final decision was a combination of these, confining the first portion of the hearings to requests for non-consumptive permits upstream from Folsom Dam. ${ }^{23}$ This was made possible by the District's announcement that it would accept power permits subject to all consumptive uses, regardless of their time priority, and that it contemplated an operational agreement with the United States Bureau of Reclannation, fully protecting the Government.

The procedure followed by the State Water Rights Board was entirely satisfactory to the District and to all other participants. The necessary power permits were issued in May, and the hearings on consumptive-use applications now are proceeding expeditiously.

An agency in the power business, in addition to getting a water permit from the state, generally must secure a license from the Federal Power Commission. The Commission, established in 1920 by the Federal Water Power Act, ${ }^{24}$ has jurisdiction in all instances where the project involves a navigable stream, public lands of the United States, or the use of surplus water from a Government dam. ${ }^{25}$ Thus, any power project of consequence comes under its cognizance. Without question, the District's project fell squarely within the act.

The federal government, as well as the state, has an interest in making certain that water utilization projects (1) result in comprehensive development of each basin or (2) fit into a general plan that would have this result. Section 10(a) of the Federal Power Act provides: ${ }^{26}$

That the project adopted, including the maps, plans, and specifications, shall be such as in the judgment of the Commission will be best adapted to a comprehensive plan for improving or developing a waterway or waterways for the use or benefit of interstate or foreign commerce, for the improvement and utilization of water-power development, and for other beneficial public uses, including recreational purposes; and if necessary in order to secure such plan the Commission shall have authority to require the modification of any project and of the plans and specifications of the project works before approval.

Accordingly, one of the first tasks of the Sacramento Utility District has been to convince the Commission, in addition to the state, that its plan is satisfactory from the standpoint of comprehensive water resource development. This has been accomplished largely through submittal of plans and discussions with the regional office of the Commission in San Francisco.

There are many other federal interests which must be protected by the

23 Folsom Dam backs up a 1,000,000 acre-foot reservoir lying astride the river some twenty miles from its confluence with the Sacramento River at Sacramento.

2441 STat. 1063 (1920), as amended, 16 U.S.C. $\$ \$ 791 a-825 r$ (1952).

2541 STAT. 1066 (1920), as amended, 16 U.S.C. $\S 797$ (e) (1952).

2041 STaT. 1068 (1920), 16 U.S.C. 8803 (a) (1952). 
Federal Power Commission. One is the proper use of public lands. In the case of the District's project, most of the works will be located in the Eldorado National Forest, under the jurisdiction of the United States Forest Service. Accordingly, the Secretary of Agriculture was invited by the Commission to suggest license conditions which would adequately protect the forest land. The District found it necessary, therefore, to work closely with the Forest Service in an effort to agree on mutually satisfactory license conditions. Likewise, the Secretary of the Interior was invited to indicate conditions he felt essential to the protection of federal interests under his cognizance. Here, two Department of the Interior agencies were interested - the Bureau of Reclamation and the Fish and Wildlife Service. The Fish and Wildlife Service and the Califorma Department of Fisl and Game work closely together. To the maximum extent, the District desired to satisfy them with respect to releases from reservoirs for maintenance of fish life. The Fish and Wildlife Service, through the Secretary of the Interior, and the Fish and Game Department both made recommendations to the Federal Power Commission. The same recommendations were made by the Fish and Game Department to the State Water Rights Board. Fortunately, complete agreement with these agencies has been reached.

Of course, it is also necessary to satisfy the Federal Power Commission that the applicant's plan is engineeringly feasible. Detailed project plans must be filed and approved by the Commission's engineering staff.

In connection with both state and federal permits, there is still another group of interests which, if possible, should be satisfied. Those are the local water agencies and the counties where the water originates and where the works will be built. It is through the State Water Rights Board and the Federal Power Commission that the local entities must proceed. In the case of the Sacramento Mumicipal Utility District's Upper American River Project, the counties of El Dorado and Placer and the Georgetown Divide Public Utility District were especially interested. The District negotiated with all of these agencies and agreements satisfactory to all were concluded.

In addition to raising capital and securing state and federal permits, the power district building its own project must be in a position to firm up its hydroelectric production. The District has met this problem by entering into a firming contract with the Pacific Gas and Electric Company.

All of the problems which must be met to enable a public power district to construct a hydroelectric project have not been covered, but enough have been presented to suggest that it is a long, difficult, and costly job which slould not be contemplated without sufficient assets, an adequate engineering and legal staff, abundant "know-how", and perseverance. 